\title{
Experimental Examination of Metal Matrix Composite using EDM
}

\author{
Bharani kumar.S, Arul S, Murugan C, Sethuramalingam P, K.Mayandi
}

\begin{abstract}
The advancement of modern materials has lead to the coming out of several Metal matrix composites (MMCs), with the composition of new materials of which Aluminium metal matrix composite has widely use in current drift due to its enhanced mechanical properties. In addition to examine the mechanical behavior and its relative hardness, surface roughness. The reinforced material here used as silicon carbide particulate (SiC) with aluminum matrix has used as a based material with three different proportions. Aluminium 6061 alloy is selected as a surrounding substance alloy. The base material taken as Al 6061 is in corporate with silicon carbide with three different proportions. Three different additions of SiC were taken with the fractions of 5\%, $10 \%$ and $15 \%$. Finally testing for the material is carried out by means of the surface roughness values for the EDM machined surface and casted surface is measured and shown by means of the graphical representation. At the result a metal matrix composite of aluminium 6061 with silicon carbide $10 \%$ is found to be best of all with their specific enhancement in their surface coarseness values.
\end{abstract}

Keywords : Silicon carbide, Aluminum alloy 6061,Electric discharge machining, surface hardness.

\section{INTRODUCTION}

The Aluminium matrix composite which is chosen as a matrix material in this research has many mechanical advantages which is used for structural applications in aircraft, automotive and military industries. Lee et al(2002) experimented and proved that the aluminium has elevated strength to weight percentage, and the high rate of stiffness and good wear resistance. The article focuses on to develop a new material with additional improvement in the properties of mechanical characters.Metal matrix composites(MMC), at current is taken as base for most of the research and the wide range in research papers. The corrosiveness of the material is very less compare to other matrix material. The materials are

Revised Manuscript Received on December 15, 2019

* Correspondence Author

Bharani kumar.S ,Assistant Professor,Department of Mechanical Engineering,Rajalakshmi Institute of Technology,Chennai,India Email:sanbharani@gmail.com

Dr.Arul.S, Professor,Department of Mechanical Engineering Annamacharaya Institute of Technology and Sciences Tirupati,India

Murugan C,Assistant Professor,Department of Mechanical Engineering,Rajalakshmi Institute of Technology,Chennai,India.

Sethuramalingam P,Assistant Professor,Department of Mechanical Engineering,Rajalakshmi Institute of Technology,Chennai,India

Dr.K.Mayandi,Associate Professor,Department of Mechanical Engineering,Kalasalingam Academy of research and Education Srivilliputhur,Tamilnadu,India

chosen here as insensible and more durable as metals and the alloys are taken into beefing up material. However the accompany phase for the option depends basically on the material as choose as matrix. The white metal form the matrix for temperature application and the beefing up metal addition to the forefront suggested reasons are represent by high component. The alloys and the metals are very good in the matrices. However, in practical application, the application for the low temperature is very few. Only white metals are taken into account for their low density material as a top spot. The familiar matrix metals are magnesium, Aluminium and Titanium and the wide applications of the matrix metals are aircraft and other industries. The high modulus rigidity of the reinforcement material to the metallic matrix materials for the high strength [1].The values is higher in results of strength to weight criteria for the most of the alloys .Here the aluminium as a base metals with the addition of boron carbide, aluminium oxide and Silicon Carbide for strengthening the base metals [2].K.Umanath et al proves that the matrix has an ability to expand inter-metallic facet and other abilites as such as very fine workability, and good thermal conductivity for the reinforcement material as $\mathrm{SiC}$ and its is very chemically matched with aluminium and it forms sufficient bond at very low cost [3]. The development of hybrid materials especially in the metal matrix composites for all the engineering components with high strength and amplified wear resistance and with the elevated temperature. The reinforcement used here as SIC [4] and have the high disadvantage of wetting behaviour.The main aim to develop the metal matrix composites with $\mathrm{SiC}$ in different percentages such as three types.The validation is done for the set of mechanical properties like hardness and surface hardness. The evaluation is done for the stir casting process and the level of significance also find out in the process

\section{LITERATURE REVIEW}

The $\mathrm{SiC}$ reinforcement in the metal matrix composite is found to be more fracture resistant. The Silicon carbide particles are comparatively harder than any other reinforcement and it act as a fence for subsurface shear acting by the adjacent counter face of the steel and the end result due to the dissimilarity in the element shape. LU Et al (2011) found that Ceramic particles such as $\mathrm{SiC}, \mathrm{Al} 2 \mathrm{O} 3, \mathrm{~B} 4 \mathrm{C}$, TiC and $\mathrm{TiB} 2$ are the widely used materials for the reinforcement of aluminium Out of these $\mathrm{SiC}$ proved to be more effective when compared to other reinforcements. The silicon carbide which is used as a reinforcement material have a low density. They are one of the materials having high strength. Silicon carbides are a low thermal expansion. Their thermal conductivity is quite higher. 


\section{Experimental Examination of Metal Matrix Composite using EDM}

Their shock resistance is excellent compared to other reinforcement materials`M. Kobashi and T. Choh reveals that the silicon carbide particle is beefing up are not continuous whisker, module and granular reinforcement. Once the reinforcement increases the modulus of elasticity of the matrix is also increased. The combination of Silicon Carbide with Aluminium matrix increases the modulus of elasticity and it act as a dominant factor for increasing the modulus of elasticity[5,6]. Swamy et al 2011)Aluminium 6061 composites with silicon carbide (WC) and reinforcements, were successfully fabricated by the liquid metallurgy technique. Increasing the amount of the Silicon carbide content in the combination of metal matrix have find that the enhancement in the mechanical properties in tensile strength, hardness, and the compressive strength of the metal matrix and there is the decrease in the ductility of the material.[7,8]

\section{MATERIALS AND METHODS}

As discussed above the materials for this process is taken as aluminium 6061. The aluminium 6061 is a base material in which silicon carbide will be acting as a subtractive for the AL6061.The combination of AL6061 is mentioned in the table 1.

Table 1. Composition of Aluminum 6061.

\begin{tabular}{|l|l|l|l|l|l|l|l|l|}
\hline $\begin{array}{l}(\mathrm{Al}) \\
(\%)\end{array}$ & $(\mathrm{Cr})$ & $(\mathrm{cu})$ & $(\mathrm{Fe})$ & $(\mathrm{Mg})$ & $(\mathrm{Mn})$ & $(\mathrm{Si})$ & $(\mathrm{Ti})$ & $(\mathrm{Zn})$ \\
$(\%)$ & $(\%)$ & $(\%)$ & $(\%)$ & $(\%)$ & $(\%)$ & $(\%)$ \\
\hline 88.92 & 0.2 & 1.6 & 0.5 & 2.5 & 0.3 & 0.4 & 0.2 & 5.35 \\
\hline
\end{tabular}

The Reinforcement material is used as SiC. The Silicon Carbide material is purchased from NR Chemicals, Chennai. The F320 type of Silicon Carbide is used in the research work. The mesh Size of the $\mathrm{SiC}$ is 20 micron and the density of the material is $3.20 \mathrm{~g} / \mathrm{cm}^{3} . \mathrm{SiC}$ grain size $=300 \mathrm{ppi}$ as givenin the table 2 .

Table 2. Composition of silicon carbide.

\begin{tabular}{|l|l|l|l|l|l|}
\hline $\mathrm{SiC}$ & $\mathrm{Al}$ & $\mathrm{Fe}$ & $\mathrm{Ca}$ & $\mathrm{K}$ & $\mathrm{Mn}$ \\
\hline $73 \%$ & $3.7 \%$ & $3.5 \%$ & $1.12 \%$ & $2.45 \%$ & $1.7 \%$ \\
\hline
\end{tabular}

Since Structure acting a major position in the improvement of the performance of this metal matrix composites. The structure arrangement of $\mathrm{SiC}$ is $6 \mathrm{H}$ Hexagonal with some trigonal $15 \mathrm{R}$ and having some $4 \mathrm{H}$ Hexagonal. The carbon and silicon is chemically compounded in the silicon carbide. This type of matrix is manufactured with high temperature electrochemical response of sand with carbon. These materials have excellent abrasive and heat resistance. They are not attacked by acids or alkalies are molten salts up to $800 \mathrm{degC}$ (resistance to chemical attack). $\mathrm{SiC}$ can be able to use up to $1600 \mathrm{deg}$ C. [9-10].The Experimental investigation of the above said process is carried out by using EDM. The EDM is one of the most widely used and promising process used in the engineering field for various applications. The Electric Discharge Machining has been used almost all the areas and it will be accepted as one of the standard process in the unconventional type of the manufacturing field. The major applications of the dies are in the field of extrusion and forging . In order to machine the super alloys, metal matrix composites, and other material as with god and close precision EDM is used and the results of these are proven to be satisfactory [11-12]. Silicon Carbide can be successfully used as the most significant effective parameter in order to compare the hardness pouring temperature and stirring time by using EDM[13,14]. The material removal process is thermo electrical method is used implemented in EDM, in the method tool and work piece are coupled as two electrodes and are isolated by dielectric fluid. Electrical Discharge Machining spark corrosion is like an electrical short circuit that ignites a minute gap in a portion of metal. The electrode material and the work piece material are the conductors of the electricity are used in the EDM process. The various methods are adopted to carry out the process. Finally the fabricated material after machining is shown in figure 1.and figure 2 .

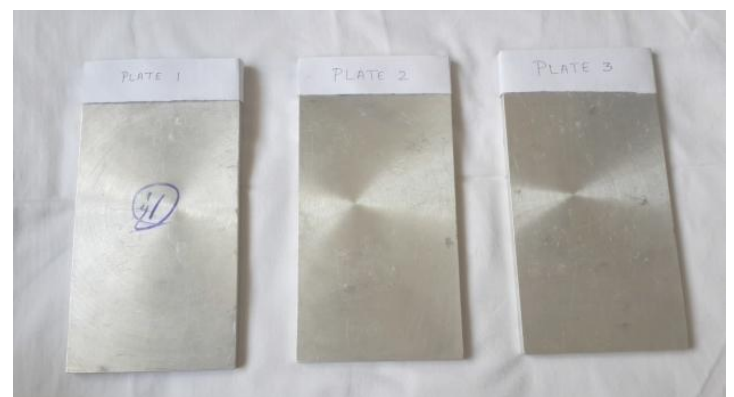

Fig1. Material after polishing the casted surface

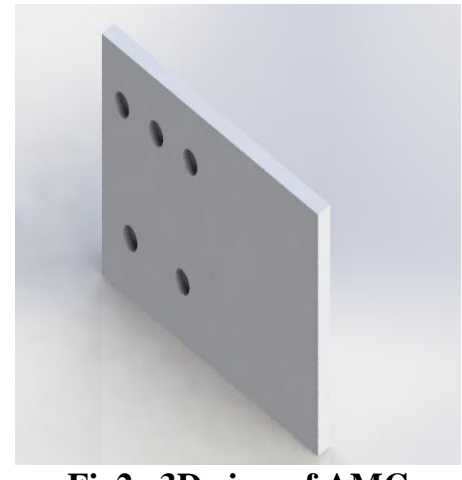

Fig2. 3D view of AMC

\section{RESULTS AND DISCUSSION.}

In this research work is carried out on the conductive metal matrix materials as Al6061 and $\mathrm{SiC}$ are selected as the materials here. The aluminium 6061 and $\mathrm{SiC}$ are the composite materials, the $\mathrm{SiC}$ as taken as $5 \%, 10 \%$ and $15 \%$ weight percentage as chosen .The plain Al6061 are also taken into account for comparing them with $\mathrm{SiC}$ mixed work pieces. The present work was done using the copper material as taken as electrode material in positive polarity. The copper electrode material diameter is $10 \mathrm{~mm}$ and height is $50 \mathrm{~mm}$. Kerosene is used as dielectric fluid in the machining process. The metal removal rate of the each set of experiment and noted before and after machining of the process and the machining was carried out in a exact time interval.

The graph(figure 3) shows that Initially flushing pressure value increases linearly the machining time of the component decreases gradually, then the values of flushing pressure again increases the machining time value decreases dramatically as the result of that the graph shows that wherever the flushing pressure value increases the machining time of the work piece it also decreases, we found that the the flushing pressure is directly propotional to the machining time is proved. 
Table. 3. Readings of EDM on plate 2 for Al-95\%

\begin{tabular}{|c|c|c|c|c|c|}
\hline \multicolumn{6}{|c|}{$\mathrm{SiC}-5 \%$} \\
\hline $\begin{array}{l}\text { Machi } \\
\text { ning } \\
\text { param } \\
\text { eters }\end{array}$ & $\begin{array}{l}\text { Curre } \\
n t\end{array}$ & $\begin{array}{l}\text { Puls } \\
\text { e on } \\
\text { time }\end{array}$ & $e^{\text {Voltag }}$ & $\begin{array}{l}\text { Flushing } \\
\text { pressure }\end{array}$ & $\begin{array}{l}\text { Machinin } \\
\text { g time }\end{array}$ \\
\hline Unit & $A$ & $\mu s$ & $V$ & Psi & Min \\
\hline 1 & 3 & 200 & 30 & 1 & 17.58 \\
\hline 2 & 3 & 300 & 40 & 2 & 15.28 \\
\hline 3 & 3 & 400 & 50 & 3 & 12.43 \\
\hline 4 & 5 & 200 & 30 & 1 & 17.22 \\
\hline 5 & 5 & 300 & 40 & 2 & 16.34 \\
\hline 6 & 5 & 400 & 50 & 3 & 13.28 \\
\hline 7 & 9 & 200 & 30 & 1 & 17.23 \\
\hline 8 & 9 & 300 & 40 & 2 & 15.22 \\
\hline 9 & 9 & 400 & 50 & 3 & 13.31 \\
\hline
\end{tabular}

Table 4. Readings of EDM on plate 2 for $\mathrm{Al}-90 \%$

\begin{tabular}{|c|c|c|c|c|c|}
\hline \multicolumn{6}{|c|}{$\mathrm{SiC}-10 \%$} \\
\hline $\begin{array}{l}\text { Machi } \\
\text { ning } \\
\text { param } \\
\text { eters }\end{array}$ & $\begin{array}{l}\text { Curre } \\
\text { nt }\end{array}$ & $\begin{array}{l}\text { Puls } \\
\text { e on } \\
\text { time }\end{array}$ & $e^{\text {Voltag }}$ & $\begin{array}{l}\text { Flushing } \\
\text { pressure }\end{array}$ & $\begin{array}{l}\text { Machinin } \\
\text { g time }\end{array}$ \\
\hline Unit & $\boldsymbol{A}$ & $\mu s$ & $V$ & $P s i$ & Min \\
\hline 1 & 5 & 200 & 30 & 1 & 15.32 \\
\hline 2 & 5 & 300 & 40 & 2 & 13.26 \\
\hline 3 & 5 & 400 & 50 & 3 & 10.13 \\
\hline 4 & 3 & 200 & 30 & 1 & 15.01 \\
\hline 5 & 3 & 300 & 40 & 2 & 12.45 \\
\hline 6 & 3 & 400 & 50 & 3 & 10.24 \\
\hline 7 & 9 & 200 & 30 & 1 & 15.12 \\
\hline 8 & 9 & 300 & 40 & 2 & 13.1 \\
\hline 9 & 9 & 400 & 50 & 3 & 10.04 \\
\hline
\end{tabular}

Table 4. Readings of EDM on plate 2

Table 5. Readings of EDM on plate 2 for Al-85\% $\mathrm{SiC}-15 \%$

\begin{tabular}{|l|l|l|l|l|l|}
\hline $\begin{array}{l}\text { Machi } \\
\text { ning } \\
\text { param } \\
\text { eters }\end{array}$ & $\begin{array}{l}\text { Curre } \\
\text { nt }\end{array}$ & $\begin{array}{l}\text { Puls } \\
\text { e on } \\
\text { time }\end{array}$ & $\begin{array}{l}\text { Voltag } \\
\boldsymbol{e}\end{array}$ & $\begin{array}{l}\text { Flushing } \\
\text { pressure }\end{array}$ & $\begin{array}{l}\text { Machinin } \\
\text { gtime }\end{array}$ \\
\hline Unit & A & $\boldsymbol{\mu s}$ & $\boldsymbol{V}$ & Psi & Min \\
\hline 1 & 5 & 200 & 30 & 1 & 10.16 \\
\hline 2 & 5 & 300 & 40 & 2 & 8.28 \\
\hline 3 & 5 & 400 & 50 & 3 & 5.36 \\
\hline 4 & 3 & 200 & 30 & 1 & 9.52 \\
\hline 5 & 3 & 300 & 40 & 2 & 8.34 \\
\hline 6 & 3 & 400 & 50 & 3 & 6.24 \\
\hline 7 & 9 & 200 & 30 & 1 & 9.24 \\
\hline 8 & 9 & 300 & 40 & 2 & 8.11 \\
\hline 9 & 9 & 400 & 50 & 3 & 6.21 \\
\hline
\end{tabular}

The micro hardness and macro hardness of the matrix are increased from $70.46 \mathrm{HV}$ to $79.46 \mathrm{HV}$ and Brinell hardness is increased from $46.21 \mathrm{BHN}$ to $58.26 \mathrm{BHN}$ with respect to adding of percentage weight proportion of $\mathrm{SiC}$ and constant weight proportion particles. The reinforcement of particles has improved from $187 \mathrm{MPa}$ to $207 \mathrm{MPa}$ in tensile strength value. The Hardness values for AL6061 With SiC proportions is studied and the values are plotted below in table 6 .

\section{Flushing Pressure Vs Machining Time}

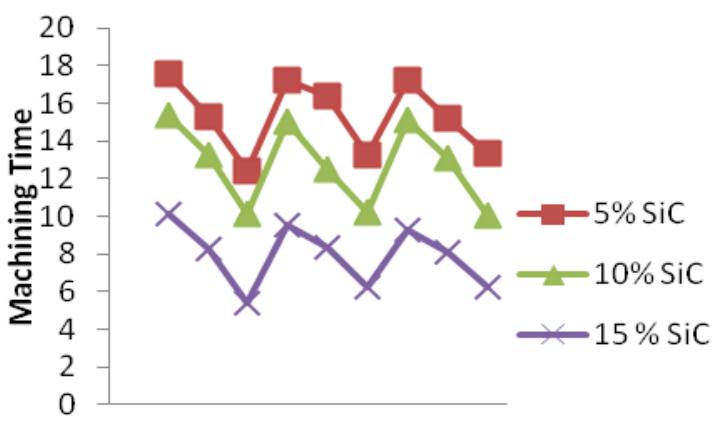

$\begin{array}{llllllllll}1 & 2 & 3 & 4 & 5 & 6 & 7 & 8 & 9 & 10\end{array}$

Flushing Pressure

Fig3.Graph Flushing Pressure Vs Machining Time

Table 6. Hardness value

\begin{tabular}{|l|l|l|}
\hline Sl.NO & $\begin{array}{l}\text { Al6061-Sic } \\
\text { Proportions }\end{array}$ & $\begin{array}{l}\text { Hardness } \\
\text { values }\end{array}$ \\
\hline 1 & 5 & 70.46 \\
\hline 2 & 10 & 79.46 \\
\hline 3 & 15 & 77.26 \\
\hline
\end{tabular}

The tensile strength variation is very large as compared to the hardness value of the composites its play the major role of the composites .Also results shows that the cruelty of surface of the material increases the Material removal rate in the Electrical Discharge Machine. The work also states that the ultimate strength of the $15 \% \mathrm{SiC}$ is increases from $139 \mathrm{MPa}$ to $242 \mathrm{MPa}$.the Hardness test shows that EDM process softening the material upto the deepness of 200micron just above the recast layer. The rougher surface can be attained by using the EDM process, the Ra values is increasing comparing to the prior values from 8.26 to 5.89 . The slight changes in the improvement path of the material and it simplifies the procedure of the optimization.

\section{CONCLUSION.}

The work shows that the metal matrix composite was formed for the various propotions of aluminium 6061 with Silicon carbide .The various promotions like $5 \%, 10 \%$ and $15 \% \mathrm{SiC}$ to Aluminium 6061 are formed. The test was carried out for the three specimens. In the research work the process shows that the composite material hardness is increased compare to plain aluminium and surface roughness have progressively been amplified on the holes were electrical discharge machining was prepared .From the results was tabulated, we can survey that $\mathrm{Al} 6061 / \mathrm{SiC}$ has satisfied the condition given from literature survey. From the work we carried out the following results was found. There is regular increase in the surface roughness at the surface where EDM is done compared to the casted surface from the graphs viewing the values. 


\section{Experimental Examination of Metal Matrix Composite using EDM}

The values of surface roughness increases nearly up to $12 \%$.the hardness value of the aluminium metal composites also raised compared to the aluminium metal.

The new material is suitable for low weight to having higher strength with a larger surface roughness rate and its machined with EDM too.

\section{REFERENCES}

1 A. Al-Rashed, S. Holecek, M. PrazAk, M. Procio. "Powder metallurgy route in production of aluminium alloy matrix particulate composites", Journal de Physique IV, (C7), pp.C7-1821-C7-1823, 1993, 03.

2 Hybrid Aluminium Metal Matrix Composite Reinforced With SiC and TiB2 Johny James.Sa, Venkatesan.Kb, Kuppan.Pc*, Ramanujam.Rd Procedia Engineering 97 ( 2014 ) 1018 - 1026

3 K.Umanath, Analysis of dry sliding wear Behavior of A16061/SiC/Al2O3 hybrid metal matrix composites.Material Science Jounal Bharath University, Chennai, India

4 J.M.Martin, T.omezacebo,And F. Castro , "Sintering behaviour and mechanical properties of $\mathrm{PM} \mathrm{Al}-\mathrm{Zn}-\mathrm{Mg}-\mathrm{Cu}$ alloy containing elemental Mg additions" Article in Powder Metallurgy. pp.173-180, July 2002 .

5 ChinawadDhadsanadhepl,TachaiLuangvaranunt, Junko Umeda and Katsuyoshi Kondoh. "Fabrication of Al/A12O3 Composite by Powder Metallurgy Method from Aluminum and Rice Husk Ash" Journal of Metals, Materials and Minerals. Vol.18 No.2, pp.99-102, 2008.

6 MortezaEslamian, Joel Rak, Nasser Ashgriz, "Preparation of aluminium /silicon carbide metal matrix composites using centrifugal atomization", Powder Technology, Volume 184,Issue 1, pp 11-20, May 2008.

7 M.Muratoglu,O.Yilmaz, M. Aksoy, "Investigation on diffusion bonding characteristics of aluminium metal matrix composites $(\mathrm{Al} / \mathrm{SiCp})$ with pure aluminum fordifferent heat treatments", Journal of Materials Processing Technology, pp 211-217, (2006)

8 Dolata-Grosza,J.Sleziona,"Structure and properties of aluminium cast compositesstrengthened by dispersion phases" Journal of material Processing Technology, Vol 175 ,Issue 1-3, pp 192-197, June 2006.

9 J.DuttaMajumdar, B. Ramesh Chandra, I. Manna, "Friction and wear behavior of laser composite surfacedaluminium with silicon carbide" Wear, Vol 262 , Issue 5-6, pp 641-648,Feb 2007

10 Barbara Previtalia,DantePocci b, Cataldo Taccardo. "Application of traditional investment casting processto aluminium matrix composites" Composites Part-A, Vol 39, Issue 10, pp 1606-1617, Oct 2008

11 K.H. Ho, S.T. Newman, State of the art electrical discharge machining (EDM), Int. J. Mach. Tools Manuf. 43 (2003) 1287-1300.

12 S. Singh, S. Maheshwari, P.C. Pandey, Some investigations into the electricdischarge machining of hardened tool steel using different electrodematerials, J. Mater. Process. Technol. 149 (2004) 272-277.

13 S. B. Rayjadhav Development of Aluminum 6061-Sic Composite and It's use in Manufacturing of Dovetail by Single Response Optimization of Hardness and Surface Roughness by Taguchi Method in Stir CastingInternational Journal for Innovative Research in Science \& Technology| Volume 2 | Issue 09 | February 2016

14 S. Singh and M.F Yeh., 2016, Optimization of Abrasive Powder Mixed EDM of Aluminium Matrix Composites with Multiple Responses using Gray Relation Analysis, Journal of Materials Engineering and Performance 21:481-491

15 Erden, A. and S. Bilgin., 1980, Role of impurities in electric discharge machining 21st International Machine Tool Design and Research Conference, pp. 345-350, Macmillan, London.

16 Hu, F. Q., F.Y Cao, B.Y Song, P.J Hou, Y Zhang, K Chen, J.Q Wei., 2016, Surface properties of SiCp/Al composite by powdermixed EDM, Procedia CIRP, Vol.6 $101-106$

17 S.Bharani kumar \& Arul S, Examination on surface roughness in EDM of aluminium 6061 reinforced with $5 \% \mathrm{SiC}$ using design experiments, Applied Mechanics and Materials, Trans Tech Publications, Vol 813814 (2015),526-530.

18 S.Bharani kumar \& Arul S, Influence of silicon carbide particle addition in the aluminum (Al6061) Composite on EDM process parameter, Int. Journal. Chemical Science, Sad guru publications,Vol14(4),2016,3157-3166.

19 S.Bharani kumar \& Arul S, CienciaeTecnica vitivinicola, A science and Technology Journal.,Vol,XX(n.XX,XX),2019,3157-3166.

\section{AUTHORS PROFILE}

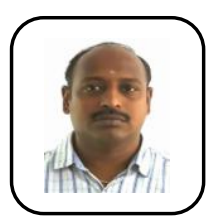

Bharani kumar $\mathbf{S}$ is finished is bachelor of engineering in madras university, post graduate in Anna university and he published six articles in various journals and doing his research in the field of MMC and Machining.
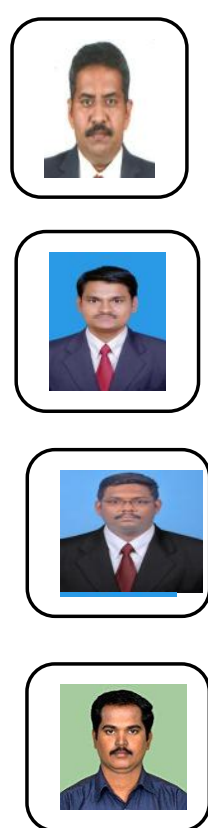

Dr.Arul S is finished the post graduate in IIT Madras, and the doctorate in the field of composites and machining in IIT Madras. His research topic is composites and he published huge number of journal papers in various journals.

Murugan $\mathbf{C}$ is finished is bachelor of engineering in madras university, post graduate in Anna university and he published three articles in various journals and doing his research in the field of $3 \mathrm{~d}$ printing

Sethuramalingam $\mathbf{P}$ is finished is bachelor degree and post graduate in manufacturing engineering under Anna university and he published three articles in various journals and doing his research in the field of $3 \mathrm{~d}$ printing and polymers.

Dr.K.Mayandi is finished is bachelor of engineering in , post graduate in Anna university and he published huge number of articles in various journals and doing his research in the field of polymer composites . 